Original Article

\title{
ANTIMICROBIAL ACTIVITY OF CALLYSPONGIA DIFFUSA (MARINE SPONGE) ASSOCIATED ENDOPHYTIC BACTERIA L STRAINS
}

\author{
VIJAYANAND B. WARAD ${ }^{* 1}$, PRASANNA HABBU ${ }^{2}$, RAJESH SHASTRI ${ }^{2}$ \\ ${ }^{1}$ Research Scholar PRIST University, Vallam, Thanjavur 613403, Tamilnadu, India, ${ }^{2}$ Postgraduate Department of Pharmacognosy and \\ Phytochemistry, S E T's College of Pharmacy, Dharwad 580002, Karnataka, India
}

Email: vijayanandwarad@gmail.com

Received: 19 Mar 2017 Revised and Accepted: 19 May 2017

\begin{abstract}
Objective: To screen the antimicrobial activity Of Callyspongia Diffusa (Marine Sponge) Associated Endophytic Bacterial Strains.

Methods: We have isolated endophytic bacterias CDB-1 and CDB-2 from marine sponge Callyspongia diffusa and identified as Pseudomonas taiwanensis strain and Lysinibacillussphaericus strain respectively by the phylogenetic analysis. Fractions of CDB-1 and CDB-2 were screened for in vitro and in vivo antimicrobial activities against pathogenic bacteria and mycobacterium tuberculosis $\mathrm{H}_{37} \mathrm{RV}$ strain by Minimum Inhibitory Concentration (MIC) method.
\end{abstract}

Results: The lowest MIC against Kleibesella pnumoniae, Escherichia coli and Enterococcus feacalis was found to be $0.2 \mu \mathrm{g} / \mathrm{ml}$ and $0.4 \mu \mathrm{g} / \mathrm{ml}$ respectively for CDB-2. A significant antifungal activity was observed against Candida albicans (0.2-0.8 $\mu \mathrm{g} / \mathrm{ml})$ and Aspergillus niger (0.2-0.4 $\mu \mathrm{g} / \mathrm{ml})$. Further, Chloroform fraction of CDB-1 and ethyl acetate fraction of CDB-2 have shown significant anti-tubercular activity against the tested organism with MIC of $6.25 \mu \mathrm{g} / \mathrm{ml}$. This was supported by in vivo antimicrobial activity against $K$. Pneumonia infection in mice and least haemolytic activity against erythrocytes was observed. Compared to chloramphenicol.

Conclusion: In this study, we have reported the marine natural species offer a rich source of bioactive metabolites that can exploit to develop novel, useful and potential therapeutic agents.

Keywords: Antimicrobial, Anti-tubercular, Pseudomonas taiwanensis, Lysinibacillus sphaericus, Callyspongia diffusa, Endophytic bacteria

(C) 2017 The Authors. Published by Innovare Academic Sciences Pvt Ltd. This is an open access article under the CC BY license (http://creativecommons.org/licenses/by/4.0/) DOI: http://dx.doi.org/10.22159/ijpps.2017v9i7.18480

\section{INTRODUCTION}

For the treatment of the treatment of many infectious diseases, resistances of antimicrobial compounds by the micro-organisms have become a universal problem. Several infections caused by multidrug-resistant organism threaten the human health. In developed and developing countries tuberculosis (TB) is a main infectious disease. It is projected that out of 3 persons one will be infected with TB. Particularly in Asia and sub-Saharan Africa. The occurrence of TB in India is around 30\%, whereas in China around $40 \%$ [1]. Nearly around two million people will die due to TB, with a world case fatality rate of $24 \%$ and it is reaching more than $50 \%$ in African countries. In India because of more rates of co-existing HIV infection. A person infected with HIV is more susceptible to TB [2]. Even though various treatment regimens for tuberculosis, still it is major problem in so many areas of the world because of drug resistance strains. Thus there is a great need in discovering effective and alternative antimicrobial compounds. In biomedical research, the formulation and improvement of the new antimicrobial drug from a natural source is of great importance. Many antimicrobial agents have been invented by continuous efforts [3].

In the last two decades, research work on natural products obtained from marine plants and animals are the principal focus. Marine environment is the rich source of bioactive constituents with numerous health beneficial effects. Among these organisms, marine sponge and algae species have been pointed as on under-exploited plant resources, even though they have long been identified as valuable sources of structurally diverse bioactive metabolites [4].

In recent times, sponge metabolites are attracting to huge attention, and the topics have been discussed by a number of authors. Sponges, exclusively are aquatic and mostly marine, are found from the deepest oceans to the edge of the sea. A total of 486 species of sponges has been identified in India [5]. Since 1974, when the first sponge-derived natural products become part of the pharmacopoeia (e. g., cytarabine and vidarabine), marine natural products have gained much research interest $[6,7]$. So far, over 20,000 natural products have been isolated and identified from various marine organisms [8].

In general, sponge research is yielding more than 200 new pharmacologically active metabolites per year at present, and several compounds that are derived from sponges or from spongeassociated bacteria are in different phases of clinical trials [9].

Sponges are a rich source of sterols, sulphates and alkaloids. From Micronesian sponge, new sesquiterpene quinols were isolated which possess potent antimicrobial activity [10].

Marine endophytes are of huge interest as rich and novel sources of biologically active compounds. They exist in close relationship with soft-bodied marine organisms, which not have clear structural protection mechanisms, and thus rely on chemical protection by the production of secondary metabolites, either by associated microflora or by themselves, to stay alive in their intense habitat [11]. Throughout the years, wide screening programs were developed worldwide and immense efforts have been dedicated aiming of the isolation of new bioactive metabolites from marine microorganisms. Cyclic tetrapeptides isolated from Pseudoalteromonas sp and Pseudomonas sp. of seaweed Diginea $s p$ [12], $\alpha$-campholene aldehyde and Lucenin-2 from endophytic fungus aspergillus ochraceus MP2 of marine sponge [13], Ariakemicins A and B from endophytic bacteria Rapidithrixsp of marine source [14], 1-(2, 6-dihydroxyphenyl) pentan-1-one from endophytic bacteria Cryptopsoriopsissps of Clidamiahirta plant [15], 1, 3,8-Trihydroxy-6methoxy anthraquinone from endophytic bacteria Curvularialunata of the marine sponge Niphatesolemda [16]. These are some important antimicrobial secondary metabolites obtained from marine sponge derived endophytic microbes.

Callyspongia diffusa is a member of a marine sponge, reported to possess antioxidant and antimicrobial activities $[17,18]$. Metabolites 
were isolated from Virgibacillus sp. associated with Callyspongia diffusa reported the antimicrobial and antioxidant activity [17]. The bacterial strain (CSD 1-CSD10) of Callyspongia diffusa showed antimicrobial and immunomodulatory activity [17]. Isolation of bioactive proteins from bacterial species (Pseudomonas aeruginosa, $V$. cholera) associated in Callyspongia diffusa, and also isolated proteins showed antibacterial activity [20]. The aim of this study was to isolate the microorganisms (endophytes) from the marine natural species which are good candidates for studying, associated microbes and the production of novel secondary metabolites, and which is a great need in finding new classes of natural products that may be effective against resistant strains of microbes, especially from bioactive endophytes from marine source due to their rich source of secondary metabolites and least toxic effects.

\section{MATERIALS AND METHODS}

\section{Chemicals used}

Sodium hypochlorite, Distilled water, Tetracycline, Almar blue reagent, Alcohol procured by Sigma-aldrich Chemicals pvt ltd, Bangalore, India, and remaining all the chemicals purchased from good companies.

\section{Instruments used}

Laminar air flow (Reschlor), Autoclave (Natsteel), Incubator (Tempo), Refrigerator or deep freezer (Remi), the Rotary flash evaporator (Superfit) etc.

\section{Collection and authentication of marine sponge}

Sponge sample was collected with the help of fisher mans during the lowest low tide from the intertidal zone of Majaahalli beach, Karwar, Karnataka, India in October 2016. It was authenticated as Callyspongia diffusa by Dr. Pratibha Rao, Scientist-in-charge, Central Marine Fisheries research institute, Mangalore, Karnataka, India. The voucher specimen of the algae (Voucher Nos. 14 to 15) was deposited at Pharmacognosy Department, SET's Pharmacy College, Dharwad, Karnataka, India.

\section{Isolation of endophytes from Callyspongia diffusa}

The samples were washed with sterile seawater after collection, to remove linked debris. Epiphytes were detached of the sponge. The cleaned sponge material was then surface dried out by pressing it for a short time between paper sheets of towelling and air dried at $30{ }^{\circ} \mathrm{C}$ in the shade during $24 \mathrm{~h}$. The microflora present in the surface was detached by washing the sponge samples for 10 to $15 \mathrm{~min}$ with $30 \%$ ethanol [21]. Then the sample of algae was surface sterilized by $4 \%$ sodium hypochlorite for $5 \mathrm{~min}, 1 \mathrm{~min}$ with $70 \%$ ethanol and 1 min 2-3 times with distilled water. The sterilized pieces were transferred to alcohol sterilized mortar and triturated into suspension by using distilled water and made the serial dilutions. The diluted suspensions were transferred on sterilized nutrient agar plate. After incubation for $4-5 \mathrm{~d}$ at $30{ }^{\circ} \mathrm{C}$, picked up predominant isolates of bacteria and purified. The chosen isolates were experimental their morphological characteristics $[22,23]$.

\section{Fermentation and preparation of crude fractions}

Pure isolated bacteria are grown in nutrient agar plates for 4-5 d at $30{ }^{\circ} \mathrm{C}$. These isolated bacteria are identified and given a name as CDB- 1 and CDB- 2 respectively. CDB- 1 and CDB- 2 endophytes used for fermentation and extraction process. Purified bacterial isolates were inoculated and fermented individually in Erlyenmeyer flask having nutrient broth for $7-14 \mathrm{~d}$ at $30{ }^{\circ} \mathrm{C}$ under immobile condition. Each broth of bacteria was filtered through 4 layers of cheesecloth and homogenized at 4,000 rpm to squeeze the bacterial cells from broth. The filtrate was solvent extracted with chloroform and ethyl acetate three to four times respectively. Then organic part was separated and dried under reduced pressure using rotary evaporator (SuperfitRotavap, PBU-6) and weighed the crude extract. In this study, CDB-1 and CDB-2 were taken for in vitro and in vivo antimicrobial activity and further endophytes characterization was studied by sequential analysis. The yield of every extract ranged from $60-80 \mathrm{mg} / \mathrm{l}$ of fermented medium [23]. Chloroform and ethyl acetate fractions of $\mathrm{CDB}-1$ and $\mathrm{CDB}-2$ were also subjected to preliminary phytochemical investigations to identify the presence of secondary metabolites.

\section{Study design}

\section{Test organisms}

Aspergillus niger, Candida albicans, Enterococcus fecalis, Kleibesella pnumoniae, Bacillus subtilis, Escherichia coli. Which are obtained from Microbiology Laboratory, KMC Mangalore, Karnataka, India.

\section{In vitro antimicrobial activity}

Nine dilutions of each test samples have made with BHI (Brain Heart Infusion) broth for MIC. Into the $380 \mu$ of BHI broth, $20 \mu \mathrm{l}$ of the drug was added in the initial tube. $200 \mu \mathrm{l}$ of BHI broth was added for dilutions into the remaining next 9 tubes individually. Then transferred $200 \mu \mathrm{l}$ from the initial tube to the first tube consisting $200 \mu \mathrm{l}$ of BHI broth. It was referred as $10^{-1}$ dilution, from $10^{-1}$ diluted tube to make $10^{-2}$ dilution. The above serial dilution was repetitive up to $10^{-9}$ dilution for every drug. $5 \mu \mathrm{l}$ was taken from the maintained stock cultures of necessary organisms and transferred into $2 \mathrm{ml}$ of BHI broth. In every serially diluted tube, $200 \mu \mathrm{l}$ of above suspension culture was added. Then tubes were incubated for $24 \mathrm{~h}$ and turbidity was observed [24].

\section{In vitro anti-tuberculosis activity}

The anti-TB activity of test fractions was evaluated against Mycobacterium tuberculosis $H_{37} R V$ by using Microplate Alamar Blue assay (MABA). This method is non-toxic and thermally stable reagent is using, and it shows batter correlation with BACTEC radiometric method. To minimize the evaporation of the medium in the test walls during incubation $200 \mu$ of sterile deionzed water was added to all outer perimeter wells of sterile 96 wells plate. $100 \mu \mathrm{l}$ of the Middle brook $7 \mathrm{H} 9$ broth was added in 96 wells plate, and directly on plate serial dilution of compounds was done. The final drug concentrations tested were 100 to $0.2 \mu \mathrm{g} / \mathrm{ml}$. Plates were sealed with Parafilm and it was incubated for five days at $37{ }^{\circ} \mathrm{C}$. After incubation time freshly prepared $25 \mu$ of 1:1 mixture of Almar Blue reagent and $10 \%$ tween 80 was added to the plate and incubated for $24 \mathrm{~h}$. A blue color in the well was indicated as no bacterial growth and pink color indicates as the growth of bacteria. The MIC was defined as the lowest concentration of the drug that prevents the colour change from blue to pink [25].

\section{Analysis of cellular toxicity to human erythrocytes}

Chloroform and ethyl acetate endophytic fractions of CDB-1 and CDB-2 were further investigated for cellular toxicity of RBC's. Blood was obtained from blood bank of KMC hospital, Hubli, karnatak, India. Human erythrocytes were isolated from the blood by removing the buffy coat and suspended in PBS $(10 \mathrm{mmol}$ phosphates, $150 \mathrm{mmol}$ sodium chloride, $\mathrm{PH}$ 7.4) which were dispensed in sugar tubes $(10[10]$ cells/500 $\mu$ l/tube). The serial dilutions of endophytic fractions were made and mixed with erythrocytes keeping the final volume of $1 \mathrm{ml}$. The cells were incubated for $1 \mathrm{hr}$ at $37^{\circ} \mathrm{C}$ and finally centrifuged at $1500 \mathrm{~g}$ for $10 \mathrm{~min}$. Lysis of the cells was observed by determining absorbance at $600 \mathrm{~nm}$ using a colorimeter. The respective dilution of test compounds (without erythrocytes) was used as blank for determination of absorbance. The erythrocytes were completely lysed by treatment with $1 \%$ Triton-X100 and absorbance of the released haemoglobin was taken as $100 \%$ lysis [26].

\section{In vivo antimicrobial activity}

Swiss mice of both male and female (20-22 gms) were used in the study. Standard pellet diet and water ad libitum were given to all the animals. Were given a. Daily animals were checked for their mortality and morbidity till the commencement of the study and only healthy animals were used in the experiment. Techniques used in the experiment like injection, bleeding and sacrifice of the animal were approved by the Animals Ethics Committee as per CPCSEA guidelines (SDCP/IABC/2014-2). Each animal was challenged by $5 \mathrm{X}$ $10^{5}$ viable Kneumoniae bacteria in $0.9 \%$ of normal saline $(200 \mu \mathrm{l})$ through intravenous route. After $24 \mathrm{~h}$ post infection, the drug treatment was started. Suspensions of ethyl acetate and chloroform 
fractions of CDB-1 was prepared in Tween 80 and orally administered at a dose of $100 \mathrm{mg} / \mathrm{kg}$ body weight, normal saline was given to the control group. Administered the test samples for $7 \mathrm{~d}$ and necessary precautions were taken to administer a specified dose of the drug to the experimental animals.

\section{Statistical analysis}

The values were expressed in mean $\pm \operatorname{SEM}(n=6)$. The results were analyzed by using one-way analysis of variance followed by Anovatukey's multiple comparison tests to determine the statistical significance between the groups.

\section{PCR sequential analysis of 16s rRNA gene of CDB-1 and CDB-2}

The genomic DNA was isolated from the given organism using genomic DNA extraction Kit (Bhat Biotech Ltd. Bangalore, India). Amplification of the 16s rRNA gene was performed using the primers. Forward primer: 5'-AGAGTTTGATCCTGGCTCAG-3', Reverse Primer: 5'-ACGGCTACCTTGTTACGACTT-3'PCR was performed as follows in a total volume of $50 \mu$ in a $0.2 \mathrm{ml}$ thin walled PCR tube. The amplification was carried out in a Master cycler ${ }^{\circledR}$ Thermocycler (DNA-AMP Bhat Biotech) using the following program. Initial Denaturation was carried out at $94{ }^{\circ} \mathrm{C}$ for 2 min followed by 40 cycles of denaturation at $94{ }^{\circ} \mathrm{C}$ for a minute, annealing at $55^{\circ} \mathrm{C}$ for a minute and extension at $72{ }^{\circ} \mathrm{C}$ for min. Final extension was carried out at $72^{\circ} \mathrm{C}$ for $10 \mathrm{~min}$. The $\sim 1500 \mathrm{bp}$
PCR product was purified to remove unincorporated dNTPS and Primers before sequencing using PCR purification kit (GENEASY PCR PRODUCT PURIFICATION KIT). Both strands of the rDNA region amplified by PCR were sequenced by automated DNA sequence$3037 x l$ DNA analyzer from Applied Biosystems using BigDye ${ }^{\circledR}$ Terminator v3.1 cycle sequencing Kit (Applied Biosystems). Sequence data were aligned and dendrograms were generated using sequence analysis software version 5.2 from applied biosystems.

The sequences obtained for plus and minus strands were aligned using the appropriate software before performing bioinformatics. Sequences were compared to the non-redundant NCBI database using BLASTN, with the default settings used to find sequences closest to each other. The Expected value ande values were noted for the most similar sequences. Ten similar neighbours were aligned using CLUSTAL W2. The multiple alignment files thus obtained was then used to create a phylogram using the MEGA5 software.

\section{RESULTS}

The yield of chloroform and ethyl acetate fractions were found to be $0.6 \mathrm{gm} / \mathrm{l}$ and $0.7 \mathrm{gm} / \mathrm{l}$ for CDB-1 and $0.8 \mathrm{gm} / \mathrm{l}$ and $0.7 \mathrm{gm} / \mathrm{l}$ for CDB2 respectively. Preliminary phytochemical investigations of CDB-1 and CDB-2 fractions showed the presence of alkaloids, steroids, triterpenoids and flavonoids as important constituents (table 1).

Table 1: Qualitative phytochemical analysis of endophytic fractions of Callyspongia diffusa

\begin{tabular}{|c|c|c|c|c|c|c|c|}
\hline S. No. & Endophytic fractions & Carbohydrates & Flavonoids & Alkaloids & Steroids & Tannins & Triterpenoids \\
\hline 1 & CDB-1 (Chloroform) & + & - & + & + & - & + \\
\hline 2 & CDB-2 (Chloroform) & + & _- & + & + & - & + \\
\hline 3 & CDB-1 (Ethylacetate) & + & + & + & + & - & + \\
\hline 4 & CDB-2 (Ethylacetate) & + & + & + & + & - & + \\
\hline
\end{tabular}

Endophytic fractions: $(+)$ indicates the presence of the component, (-) indicates complete absence of the component

Table 2: Efficacy of different endophytic fractions of Callyspongia diffusa against pathogenic bacteria and fungi

\begin{tabular}{|c|c|c|c|c|c|}
\hline \multirow[t]{2}{*}{ S. No. } & \multirow[t]{2}{*}{ Test organism } & \multicolumn{2}{|c|}{ CDB-1(MIC- $\mu \mathrm{g} / \mathrm{ml})$} & \multicolumn{2}{|c|}{ CDB-2(MIC- $\mu \mathrm{g} / \mathrm{ml})$} \\
\hline & & C & $\mathbf{E}$ & $\mathbf{C}$ & $\mathbf{E}$ \\
\hline 1 & Bacillus subtilis & 0.2 & 100 & 3.12 & 100 \\
\hline 2 & Escherichia coli & $>100$ & 100 & 0.4 & 0.4 \\
\hline 3 & Enterococcus fecalis & 1.6 & 100 & 0.4 & 0.4 \\
\hline 4 & KlebsiellaPnumoniae & $>100$ & 50 & 0.2 & 0.2 \\
\hline 5 & Candida albicans & 0.2 & 0.4 & 3.2 & 0.8 \\
\hline 6 & Aspergillus niger & 0.4 & 6.25 & 0.2 & 0.2 \\
\hline
\end{tabular}

C-Chloroform fraction, E-Ethyl acetate fraction

The results of antimicrobial activities (MIC) of the compounds against the selected two Gram-positive, two Gram-negative bacteria and two fungi are shown in (table 2).

The activity of ciprofloxacin and norfloxacin are used for comparison. All the compounds showed moderate to significant microbial inhibition. Chloroform fractions of CDB-1 and CDB-2 have shown MIC of $0.2,3.12 \mu \mathrm{g} / \mathrm{ml}$ against Bacillus subtilis respectively, whereas MIC of ethyl acetate fractions was more than $100 \mu \mathrm{g} / \mathrm{ml}$. The MIC of chloroform and ethyl acetate fractions of CDB-2 against Eschereichia coli was found to be $0.4 \mu \mathrm{g} / \mathrm{ml}$ respectively. The lowest MIC against Enterococcus fecalis among the fraction tested was 0.4 $\mu \mathrm{g} / \mathrm{ml}$ for CDB-2 followed by $1.6 \mu \mathrm{g} / \mathrm{ml}$ for chloroform fraction of CDB-1. Chloroform and ethyl acetate fraction of CDB-2 has shown
MIC of $0.2 \mu \mathrm{g} / \mathrm{ml}$ against Kleibesella pnumoniae. A significant antifungal activity was observed against Candida albicans (MIC range 0.2-3.2 $\mu \mathrm{g} / \mathrm{ml}$ ) and Aspergillus niger (MIC range 0.2-6.25 $\mu \mathrm{g} / \mathrm{ml}$ ).

In antitubercular assay against Mycobacterium tuberculosis $H 37$ $R V$ strain, chloroform fraction of CDB-1 and ethyl acetate fraction of CDB-2 has shown MIC of $6.25 \mu \mathrm{g} / \mathrm{ml}$ respectively. However, the MIC for ethyl acetate fractions of CDB-1 and chloroform fraction of CDB-2 was found to be $12.5 \mu \mathrm{g} / \mathrm{ml}$. The results are shown in (table 3).

Results of haemolysis assay suggested that ethyl acetate fractions of CDB-1and CDB-2 caused least haemolysis erythrocytes as compared to chloramphenicol (fig. 1).

Table 3: Antitubercular activity of different endophytic fractions of Callyspongia diffusa against Mycobacterium tuberculosis H37 sensitive strain

\begin{tabular}{|c|c|c|}
\hline \multirow{2}{*}{ Endophytic fractions } & \multicolumn{2}{|c|}{$\operatorname{MIC}(\mu \mathrm{g} / \mathrm{ml})$} \\
\hline & C & $\mathbf{E}$ \\
\hline CDB-1 & 6.25 & 12.5 \\
\hline CDB-2 & 12.5 & 6.25 \\
\hline
\end{tabular}

C-Chloroform fraction, E-Ethyl acetate fraction 


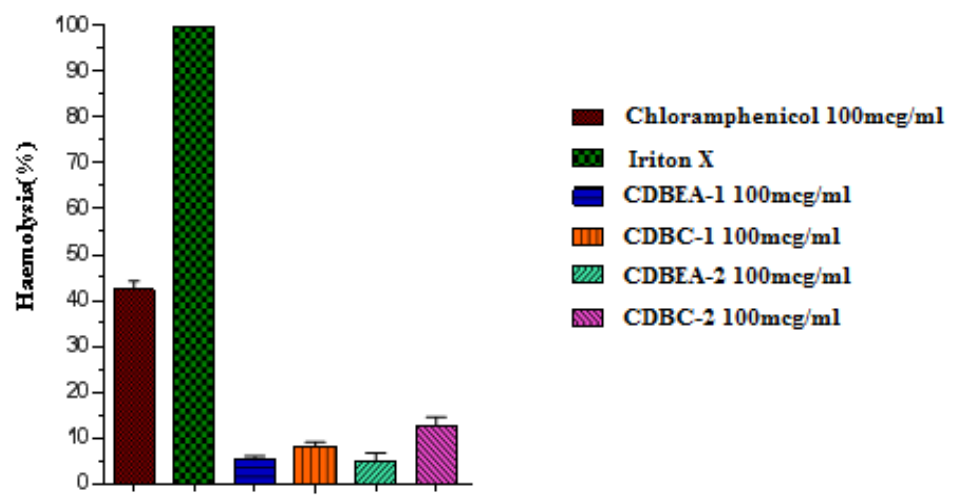

Conc of drugs

Fig. 1: Effect of chloroform and ethyl acetate fractions of CDB-1 and CDB-2 on the cellular toxicity of RBCs. (The values are mean \pm S. E. M of three experiments)

In vivo studies demonstrated the survival data on day $10^{\text {th }}$ of posttreatment of CDB-1 endophytic fractions. The results showed that about $40 \%$ of animals treated with chloroform fraction and $60 \%$ of animals treated with ethyl acetate fraction of CDB-1 were survived respectively. All the control animals died within $6 \mathrm{~d}$. The results are shown in (table 4).

Table 4: Efficacy of endophytic fractions of Callyspongia diffusa on K. Pneumonia infection in mice

\begin{tabular}{|c|c|c|c|c|c|c|c|c|c|c|c|}
\hline \multirow[t]{2}{*}{ Test compounds } & \multicolumn{11}{|c|}{ No. of days/percentage of protection } \\
\hline & 0 & 1 & 2 & 3 & 4 & 5 & 6 & 7 & 8 & 9 & 10 \\
\hline Control & 100 & 100 & 100 & 85 & 75 & 25 & NS & NS & NS & NS & NS \\
\hline CDB-1C & 100 & 100 & 100 & 100 & 100 & 100 & 85 & 65 & 45 & 45 & 45 \\
\hline CDB-1E & 100 & 100 & 100 & 100 & 100 & 100 & 100 & 85 & 65 & 65 & 65 \\
\hline
\end{tabular}

Swiss albino mice $(\mathrm{n}=30)$ were challenged with $5 \times 10^{5}$ efuofK. Pnumoniae. The animals were treated with CDB-1 endophytic fractions $(100 \mathrm{mg} / \mathrm{kg}$ body wt) daily for $7 \mathrm{~d}$., (CDB-1C-chloroform fraction; CDB-1 E-Ethyl acetate fraction)

The sequence of the $16 \mathrm{~s}$ gene from VBW-1 and that of matching sequences from 10 nucleotide sequences were aligned by using the
Maximum Likelihood method based on the Hasegawa-Kishino-Yano model (fig. 2).

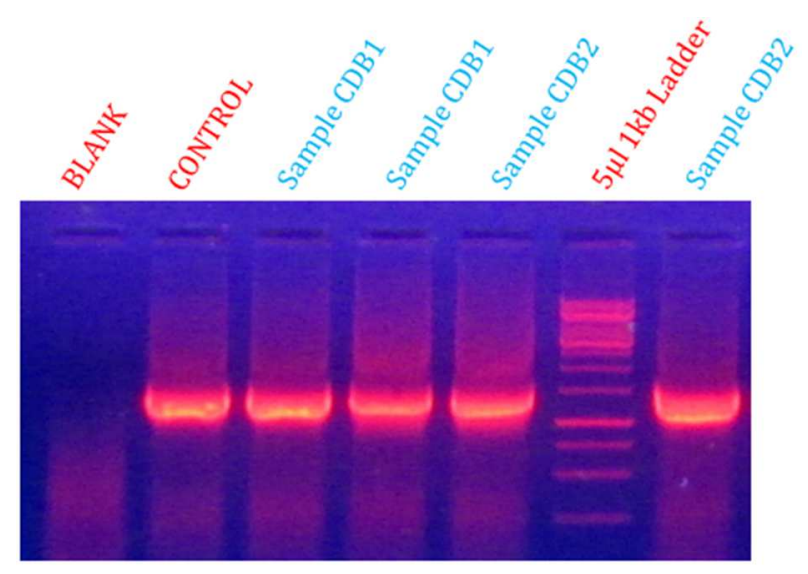

$1 \%$ agarose Gel Run At $100 \mathrm{~V}$

Fig. 2: PCR amplification of the 16s rRNA gene of CDB-1 and CDB-2

The tree with the highest log likelihood (-2346.2209) is shown. Initial tree(s) for the heuristic search were obtained automatically as follows. When the number of common sites was $<100$ or less than one-fourth of the total number of sites, the maximum parsimony method was used; otherwise, BIONI method with MCL distance matrix was used. The analysis involved 11 nucleotide sequences. Codon positions included were $1 s t+2 n d+3 r d+$ Noncoding. All positions containing gaps and missing data were eliminated. There was a total of 1293 positions in the final dataset. Evolutionary analyses were conducted in MEGA5. The sequences of CDB-1 and CDB-2 were compared with existing sequences in the NCBI database using the Blast N programme (fig. 3 and 4).

A high score and low expected value indicates the greatest homology. Based on these results CDB- 1 and CDB-2 were identified as Pseudomonas taiwanensis strain BCRC 17751and Lysinibacillus sphaericus strain DSM 28 respectively. The microscopic view of the identified organisms is shown in (fig. 5). 


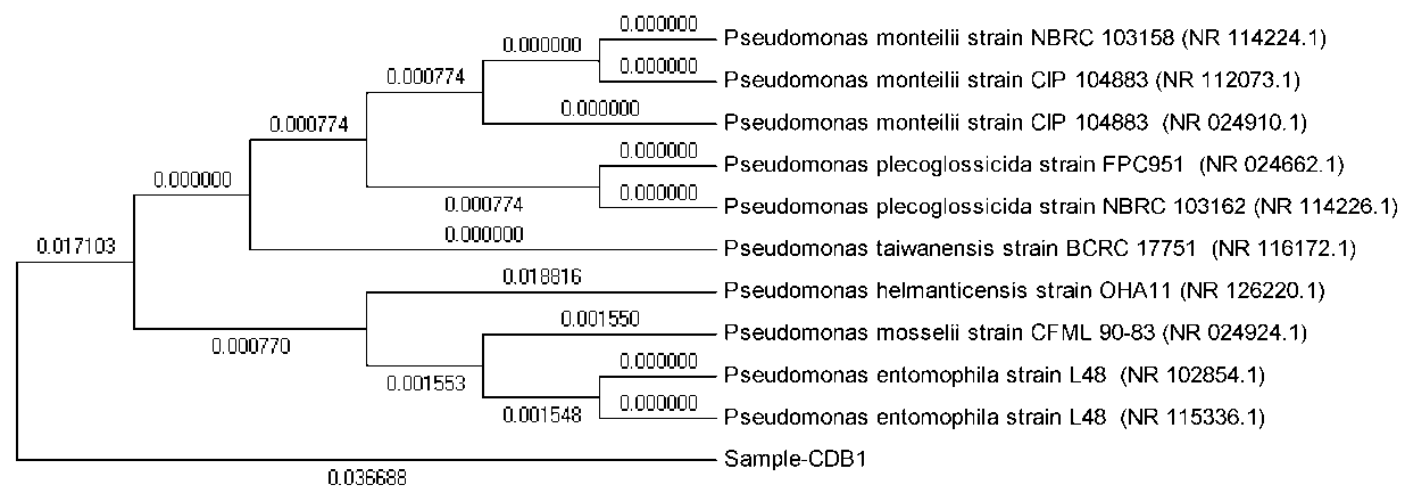

Fig. 3: Pylogenetic tree of CDB-1

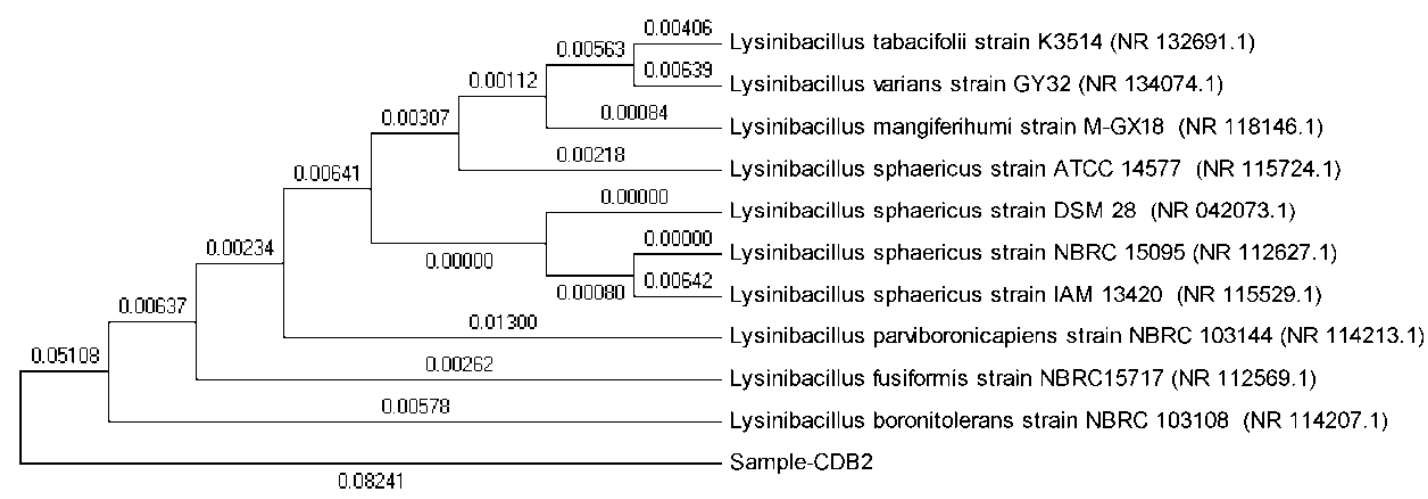

Fig. 4: Pylogenetic tree of CDB-2

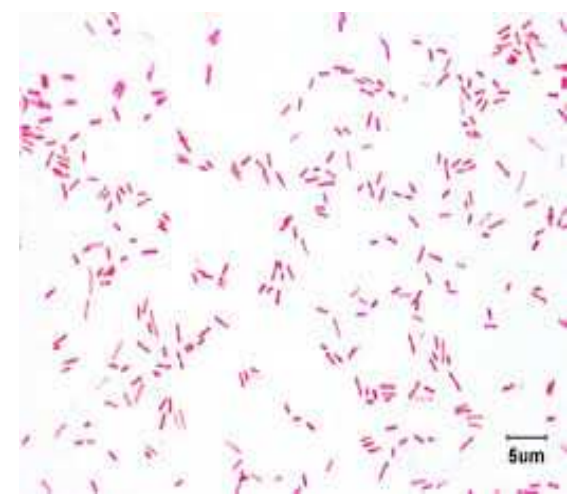

Gram-stain micrograph of Pseudomonas colonies.

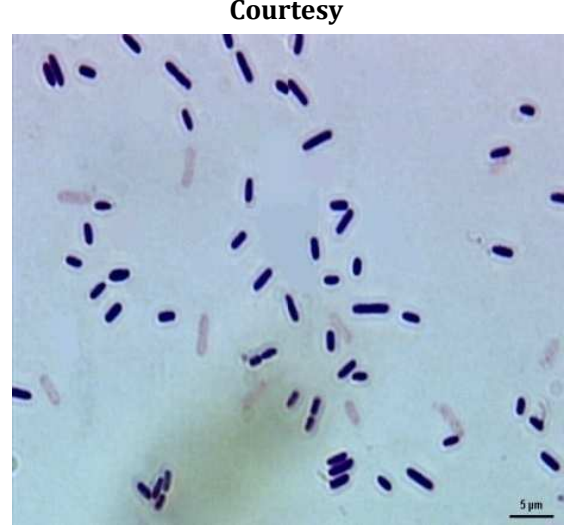

Gram-stain micrograph of Bacillus colonies. Courtesy

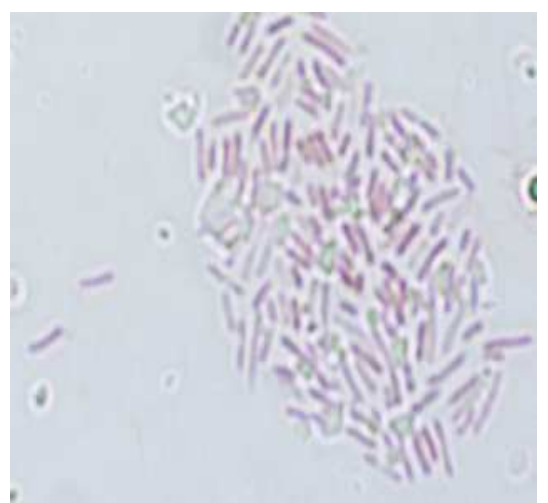

Gram-staining picture of colonies from agar slant VBW-1
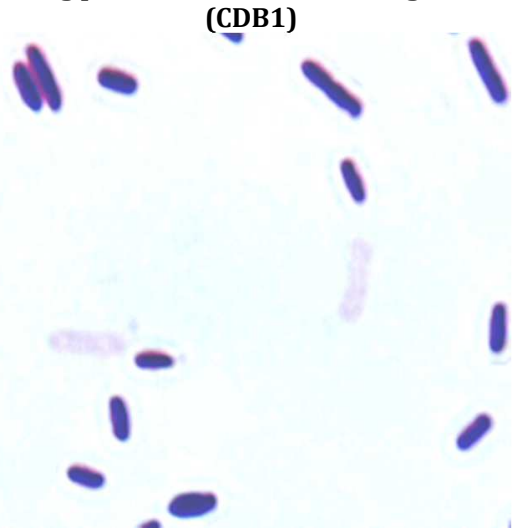

Gram-staining picture of colonies from agar slant VBW-2 (CDB2)

Fig. 5: Microscopic view of endophytic bacterial strains 


\section{DISCUSSION}

In the current investigation, we have isolated and identified two endophytic bacteria (CDB-1 and CDB-2) from Callyspongia diffusa. Through phylogenetic/sequential analysis the organisms were identified as Pseudomonas taiwanensis (CDB-1) and Lysinibacillus sphaericus (CDB-2) strains of NBRC respectively. Preliminary phytochemical analysis of CDB-1 and CDB-2 nonpolar fractions showed the presence of carbohydrates, alkaloids, steroids, Triterpenoids and flavonoids as main important constituents. Many reports suggested the marine sponge also is also a rich source of bioactive metabolites and showed the various activities. Some of the activities have been reported. i. e, Antifungal and antimicrobial activities have been reported in the tetracyclic furanoditerpenes isolated from sponge S. officinalis, Spongia-13(16), 14-dien-19-oic acid, spongia-13(16)-14-dien-19-al [27] and spongia-13(16)-14diene [28]. Sponge Luffarella variabilis contain sesquiterpenoid antibiotics, manoalide which contains alpha, beta-unsaturated gamalactone function had anti-inflammatory activity and was found to be an inhibitor of phospholipase $\mathrm{A}_{2}$ [29], tetracarbocyclic sesquiterpenes have been isolated from cacospongiascalaris namely phyllofolactore and phyllofoloctone exhibited cytotoxic activity [30]. Several peptide alkaloids and proteins have been isolated from a marine sponge, purealin, a novel enzyme activator from the okinawan marine sponge, Psammaplysillapurea modulates enzymatic reaction of ATPases [31]. Eight endophytic and two epiphytic fungi were isolated from Hymeniacidonperlevis sponge with good antimicrobial activity [32]. Diverse ranges of bioactive and potentially novel bacterial endophytes were isolated from the marine sponges Suberitescarnosus and Leucosolenia sp. It was observed that S. carnosus isolates may be a better source of antibacterial compounds, while Leucosoleniasp, isolates appear to be a better source of antifungal compounds [33]. Ten marine sponge species from Rameshwara region of southern part of India were studied for fungal diversity and their biological effects. Genera such as Acremonium, Alternaria, Aspergillus, Cladosporium, Fusarium and Penicillium were frequently isolated. Species of Aspergillus were dominant and co-dominant in all the sponges screened.

The fungal isolates produced antifungal, antioxidant, antibiotic, antiinsect metabolites. A few fungi produced acetylcholinesterase inhibitors [34]. Callyspongia diffusa is a member of a marine sponge, reported to possess antioxidant [17] and antimicrobial activities [18, 19]. Metabolites were isolated from Virgibacillussp associated with Callyspongia diffusa reported the antimicrobial and antioxidant activity. The bacterial strain (CSD 1-CSD10) of Callyspongia diffusa showed antimicrobial and immunomodulatory activity [17]. Isolation of bioactive proteins from bacterial species (Pseudomonas aeruginosa, V. cholera) associated in Callyspongia diffusa, and also isolated proteins showed antibacterial activity [20]. However, this is the first report on In vivo and In vitro antimicrobial activity of chloroform and ethyl acetate extracts of these organisms.

Antimicrobial activities of chloroform and ethyl acetate were performed against pathogenic bacteria, fungi and Mycobacterium tuberculosis H37Rv strain. Both chloroform and ethyl acetate fractions of CDB-1 and CDB-2 shown significant activity because of the presence of alkaloids, triterpenoids and steroids. Chloroform and ethyl acetate fraction of CDB- 1 and CDB-2 exhibited the lowest MIC against Kleibesella pnumoniae, Escherichia coli and Enterococcus feacalis were found to be $0.2 \mu \mathrm{g} / \mathrm{ml}$ and $0.4 \mu \mathrm{g} / \mathrm{ml}$ respectively for CDB-2. A significant antifungal activity was observed against Candida albicans $(0.2-0.8 \mu \mathrm{g} / \mathrm{ml})$ and Aspergillus niger (0.2-0.4 $\mu \mathrm{g} / \mathrm{ml}$ ). Further, Chloroform fraction of CDB- 1 and ethyl acetate fraction of CDB-2 have shown significant anti-tubercular activity against the tested organism with MIC of $6.25 \mu \mathrm{g} / \mathrm{ml}$. This was supported by in vivo antimicrobial activity against $K$. Pneumonia infection in mice and least hemolytic activity against erythrocytes was observed. The mode of action of these fractions may be due to disruption of ETC (Electron Transport Chain) and cell membrane oxidative phosphorylation, inhibition of enzyme activity, and impairment in nutrient uptake which directly leads to lyses of bacterial cells [35]. Drug resistance of mycobacterium tuberculosis has increased in existing chemotherapy regimens [36]. There is a huge need in finding novel classes of natural products that may be efficient against resistant strains of microbes, especially from Bioactive endophytes from marine source due to their rich source of secondary metabolites and least toxic effects [35].

Thus, for the biotechnological production of natural compounds endophyte seems to be the most attention-grabbing alternative and they are likely to play an important role in the years to come.

\section{CONCLUSION}

In this study, we have reported the marine natural species offer a rich source of bioactive metabolites that can exploit to develop novel, useful and potential therapeutic agents. In this study we have isolated two bacterial endophytes (CDB-1 and CDB-2) from marine sponge Callyspongia diffusa, these offers a novel source of bioactive compounds. Chloroform and ethyl acetate fractions of CDB-1 and CDB-2 showed significant antimicrobial action against pathogenic bacteria, fungi and mycobacterium tuberculosis H7Rv stain.

In vitro anti-TB activity of chloroform fraction of CDB-1 and ethyl acetate fraction of CDB-2 has shown more significant (MIC of 6.25 $\mu \mathrm{g} / \mathrm{ml}$ ) respectively. However, the MIC for ethyl acetate fractions of CDB-1 and chloroform fraction of CDB-2 has shown moderately significant (MIC of $12.5 \mu \mathrm{g} / \mathrm{ml}$ ). This was further supported by $I n$ vivo antimicrobial activity against $K$. pneumoniae infection in mice and least haemolytic activity against erythrocytes was observed. Thus, we can conclude that the antimicrobial activity of chloroform and ethyl acetate extracts of CDB- 1 and CDB- 2 may be attributed due to the presence of carbohydrates, alkaloids, steroids, triterpenoids and flavonoids as major phytoconstituents.

\section{ACKNOWLEDGEMENT}

The authors are grateful to All India Council for Technical Education (AICTE) for financial support under research promotion scheme (RPS). We also thank Dr. Pratibha Rao, Scientist-in-charge, Central Marine Fisheries Research institute, Mangalore, Karnataka, India, for identification of the marine sponge. We thank Principal SET's College of Pharmacy and President, Soniya Education Trust for encouragement and support to perform the research work. We also thankful to Dr. Jagadish V. Kamath, Principal of Shree Devi Pharmacy College Mangalore and Management of Shree Devi Education Trust for encouragement and support to carry out the research work.

\section{AUTHOR CONTRIBUTION}

I Mr. Vijayanand B Warad done the Complete research work and manuscript preparation was done by me. Prasanna Habbu was the guide of my PhD work, and he guided me in throughout the work and manuscript preparation, and third author Rajesh Shastri was the Co-guide of my PhD work, and he helped me a lot in the isolation of endophytic fractions and also guided me in throughout the work and manuscript preparation.

\section{CONFLICT OF INTERESTS}

\section{Declared none}

\section{REFERENCES}

1. George AG, Kanyawim KK, Pattama Pk, Somsaksivichai, Yodhathai T, Chawanee TP, Vanicha V. In search of cyclooxygenase inhibitors, anti-mycobacterium tuberculosis and anti-malarial drugs from Thai flora and microbes. Pharmacol Ther 2007;115:307-51.

2. WHO. Tuberculosis-A Global Emergency. In WHO/TB/1994. Geneva, Switzerland; 1994. p. 177-8.

3. Marwa D, Mark TH. Marine natural products and their potential applications as anti-infective agents. Lancet Infect Dis 2003;3:338-7.

4. Shimizu Y. Microalgal metabolites: a new perspective. Ann Rev Microbiol 1996;50:431-65.

5. V Mariya, Vinoth S Ravindran. Biomedical and pharmacological significance of marine macro algae-review. Int J Mater Sci 2013;42:527-37.

6. Molinski TF, Dalisay DS, Lievens SL, Saludes JP. Drug development from marine natural products. Nat Rev Drug Discovery 2009;8:69-85. 
7. Mayer AM, Glaser KB, Cuevas C, Jacobs RS, Kem W, Little RD, et $a l$. The odyssey of marine pharmaceuticals: a current pipeline perspective. Trends Pharmacol Sci 2010;31:255-65.

8. Hu GP, Yuan J, Sun L, She ZG, Wu JH, Lan XJ, et al. Statistical research on marine natural products based on data obtained between 1985 and 2008. Mar Drugs 2011;9:514-25.

9. Tom Turk, Jerneja Ambrozic Avgustin, Urska Batista, Gasper Strugar, Rok Kosmina, Sandra Civovic, et al. Biological activities of ethanolic extracts from deep-sea Antarctic marine sponges. Mar Drugs 2013;11:1126-39.

10. Mukku VJ, Edrada RA, Schmitz FJ, Chaudhuri B, Fabbro D. New sesqui terpene quinols from Micronesian sponge. J Nat Prod 2003;66:686-9.

11. Jensen PR, Fenical W. Strategies for the discovery of secondary metabolites from marine bacteria: ecological perspectives. Annu Rev Microbiol 1994;48:559-84.

12. Wimolpun R, Eric R, Siwu. Cyclic tetrapeptides from marine bacteria associated with the seaweed Diginea sp. and the sponge Halisarca ectofibrosa. Tetrahedron 2008;64:3147-52.

13. Liu CH, Meng JC, Zou WX. Antifungal metabolite with a new carbon skeleton from Keissleriella Sp. YS4108, a marine filamentous fungus. Planta Med 2002;68:363-5.

14. Naoya O, Kyoko A, Satoru M. Ariakemicins A and B, novel polyketide-peptide antibiotics from a marine gliding bacterium of the Genus Rapidithrix. Org Lett 2008;10:2481-4.

15. Venkat R, Macherla JL, Michelle S. Lipoxazolidinones A, B, and $\mathrm{C}$ : antibacterial 4-oxazolidinones from a marine actinomycete isolated from guam marine sediment. J Nat Prod 2007; 70:1454-7.

16. MacMillan JB, Molinski TF. Lobacyclamide B from lyngbyaconfervoides. Configuration and asymmetric synthesis of b-hydroxy-a-amino acids by sparteine-mediated aldol addition. Org Lett 2002;4:1883-6.

17. Kalirajan Arunachalam, Ranjitsingh Amirtham Jacob Appadorai. Antioxidant potential and biochemical evaluation of metabolites from the marine bacteria Virgibacillus $s p$. associated with the sponge Callyspongia diffusa. Sci Biol Med Org Phcog Net 2013;3:47-51.

18. D Isaac Dhinakaran. Antifungal and Cytotoxic activities of some marine sponges collected from the South East Coast of India. J Appl Pharm Sci 2012;2:52-5.

19. Aishwarya MS. Phylogenetic appraisal of the drug beoring marine sponge, Callyspongia Subarmigera (Ridley, 1884) from South India. Indian J Mac Sci 2013;42:139-45.

20. Boobathy $S$. Isolation of symbiotic bacteria and bioactive proteins from the marine sponge, Callyspongia diffusa. Int J Biol Technol 2009;8:272-5.

21. Hellio C, Bourgougnon N, Le-Gal Y. Phenoloxidase (E. C. 1.14.18.1) from Mytilus edulis byssus gland: purification, partial characterization and application for screening products with potential antifouling activities. Biofouling 2000;16:235-44.

22. Geraldo HS, Helder LT, Henrique CT, Vanderlan S, Bolzani MC New bioactive metabolites produced by Phomopsis cassiae, an endophytic fungus in Cassia spectabilis. J Braz Chem Soc 2005; 16:1463-6.

23. Subhash JB, Reavicharater N, Chye YL. Screening of endophytic bacteria isolated from leaves of Sambung Nyawa (Gynura Procumbens (Lour.) Merr.) for cytokine type compounds. Bioinformation 2013;5:191-7.

24. Schwalve M, Goodwin S. Antimicrobial susceptibility testing protocols, London New York: Crc Press Taylor and Francis Group: 2007. p. 6.

25. Maria CS, Lourenco Marcus V, deSouza N, Alessandra C, Pinheiro Marcelle D, Ferreira L, et al. Evaluation of the antiTubercular activity of nicotinic and isoniazid analogues. ARKIVOC 2007;181-91.

26. He X, Mocek U, Floss HG, Caceres A, Giron L, Buckley H, et al. An antifungal compound from Solanum nigrescens. J Ethanopharmacol 1994;43:173-5.

27. Thoms C, Wolf M, Padmakumar K, Proksch P. Bioactive marine natural products. Z Naturforsh 2004;59:113-4.

28. Encarnacion RD, Sandoval E, Christopherson C. Calafianin, a Bromotyrosine Derivative from the Marine Sponge Aplysina gerardogreeni. J Nat Prod 2000;63:874-5.

29. Daly JW, John W. Marine toxins and nonmarine toxins, convergence or symbiotic organism. J Nat Prod 2004;67:1211-4.

30. Stommel EW and Watters MR. Marine neurotoxins: ingestible toxins. Curr Treat Options Neurol 2004;6:105-8.

31. MacMillan JB, Molinski TF. Two novel cytotoxic benzofuran derivatives from brazilian propolis. J Nat Prod 2000;63:155-9.

32. Zhang Yi, Jun Mu, Yan Feng, Yue Kang, Jia Zhang, Peng-Juan Gu, et al. Broad-spectrum antimicrobial epiphytic and endophytic fungi from marine organisms: isolation, bioassay and taxonomy. Mar Drugs 2009;7:97-112.

33. Flemer B, Kennedy J, Margassery LM, Morrissey JP, Ogara F, Dobson ADW. Diversity and antimicrobial activities of microbes from two Irish marine sponges, Suberites carnosus and Leucosolenia sp. J Appl Microbiol 2012;112:289-301.

34. Nagamani T, Trichur S, Suryanarayanan KP, Girivasan AV, Venkatachalam G, Jagadesan $P$, et al. Fungal symbionts of marine sponges from Rameswaram, Southern India: species composition and bioactive metabolites. Fungal Divers 2012;55:37-46.

35. Andrew P, Desbois B, Valerie J, Smith K. Antibacterial free fatty acids: activities, mechanisms of action and biotechnological potential. Appl Microbiol Biotechnol 2010;85:1629-42.

36. Molina SGM, Perez LA, Becerril MP, Salazar AR, Walkman TN. Evaluation of the flora of Northern Mexico for In vitro antimicrobial and antituberculosis activity. J Ethnopharmacol 2007;109:435-7.

\section{How to cite this article}

- Vijayanand B Warad, Prasanna Habbu, Rajesh Shastri. Antimicrobial activity of Callyspongia diffusa (marine sponge) associated endophytic bacterial strains. Int J Pharm Pharm Sci 2017;9(7):90-96. 